Удк 343.3: 346.1

DOI 10.17150/2500-4255.2018.12(2).190-198

\title{
НЕКОТОРЫЕ АСПЕКТЫ ПОВЫШЕНИЯ ЭФФЕКТИВНОСТИ УГОЛОВНОГО ЗАКОНА В СФЕРЕ ЭКОНОМИКИ: PАЗРАБОТКА КАТЕТОРИААЬНОГО АППАРАТА
}

\author{
В.Н. Лисица ${ }^{1,2}$, С.В. Пархоменко 3 \\ ${ }^{1}$ Новосибирский государственный университет, г. Новосибирск, Российская Федерация \\ ${ }^{2}$ Новосибирский государственный университет экономики и управления, г. Новосибирск, Российская Федерация \\ ${ }^{3}$ Иркутский юридический институт (филиал) Академии Генеральной прокуратуры Российской Федерации, \\ г. Иркутск, Российская Федерация
}

\author{
Информация о статье \\ Дата поступления \\ 21 ноября 2017 г. \\ Дата принятия в печать \\ 6 апреля 2018 г. \\ Дата онлайн-размещения \\ 27 апреля 2018 г.

\section{Ключевые слова} \\ Предпринимательская \\ деятельность; экономическая \\ деятельность; профессиональная \\ деятельность; индивидуальные \\ предприниматели; ведение \\ предпринимательской деятельности \\ без государственной регистрации; \\ межотраслевое понятие; незаконное \\ предпринимательство
}

\begin{abstract}
Аннотация. В статье рассмотрены понятие и признаки предпринимательской деятельности как межотраслевого понятия на основе теории гражданского, предпринимательского, уголовного, административного и финансового права. Авторами подчеркивается важность эффективного решения комплекса вопросов, связанных с оптимизацией базового понятия предпринимательской деятельности, для исключения возможности использования уголовного преследования в качестве средства давления на субъектов, занимающихся предпринимательской деятельностью, в том числе при разрешении экономических споров. Это, в свою очередь, позволит исключить необоснованное привлечение к уголовной ответственности за неисполнение договорных обязательств в случаях, когда оно обусловлено обычными предпринимательскими рисками. Аргументируется недостаточность сформулированных в законодательном определении критериев предпринимательской деятельности (ее самостоятельность, осуществление на основании риска, направленность на систематическое извлечение прибыли), которое требует своего более детального уточнения, в частности путем указания на экономический вид деятельности и предпринимательский характер риска, раскрытия признака систематического извлечения прибыли и законодательного установления перечня видов деятельности, не признаваемых в качестве предпринимательской. Кроме того, в связи с исключением требования легитимации из легального определения предпринимательской деятельности обосновывается необходимость предусмотреть на законодательном уровне случаи, когда в отношении отдельных видов предпринимательской деятельности граждане могут осуществлять такую деятельность без государственной регистрации в качестве индивидуального предпринимателя. Констатируется, что поддержание в стране благоприятного делового и инвестиционного климата, как и условий для ведения бизнеса, достигается, с одной стороны, стимулированием государством законной предпринимательской деятельности, а с другой стороны, установлением обоснованных критериев криминализации деяний, совершаемых в сфере предпринимательской деятельности. В этой связи подчеркивается важность разработки анализируемого понятия для формирования криминообразующих признаков и более точной квалификации преступлений в сфере осуществления предпринимательской деятельности.
\end{abstract}

\section{SOME ASPECTS OF IMPROVING THE EFFICIENCY OF CRIMINAL LAW IN THE SPHERE OF ECONOMY: DEVELOPING THE CATEGORIES}

\author{
Valeriy N. Lisitsa ${ }^{1,2}$, Svetlana V. Parkhomenko ${ }^{3}$ \\ ${ }^{1}$ Novosibirsk State University, Novosibirsk, the Russian Federation \\ ${ }^{2}$ Novosibirsk State University of Economics and Management, Novosibirsk, the Russian Federation \\ ${ }^{3}$ Irkutsk Law Institute (branch) of the Academy of General Prosecutor's Office of the Russian Federation, Irkutsk, \\ the Russian Federation
}

\author{
Article info \\ Received \\ 2017 November 21 \\ Accepted \\ 2018 April 6
}

\begin{abstract}
The article examines the concept and qualifying features of business activity as an inter-branch law category based on the theory of civil, business, criminal, administrative and financial law. The authors stress the importance of finding efficient solutions for optimizing the basic concept of entrepreneurial activities to eliminate the possibility of using criminal prosecution to exert pressure on entrepreneurs and to solve business disputes. In its turn, this will allow
\end{abstract}


Available online

2018 April 27

\section{Keywords}

Entrepreneurial activity; economic activity; professional activity; entrepreneurs; conducting an entrepreneurial activity without a state registration; interdisciplinary concept; illegal entrepreneurship to eliminate ungrounded prosecution for non-performance of a contract in the cases caused by usual entrepreneurial risks. The authors argue that the legislatively defined criteria of entrepreneurial activities (their independence, involved risk, profit orientation) are not sufficient and should be described in more detail, specifically, by identifying the type of business activity and the entrepreneurial character of the risk, disclosing the systematic character of making a profit and legally defining activities not recognized as entrepreneurship. Besides, as the requirement of legitimization has been eliminated from the legal definition of entrepreneurial activities, the authors show that it is necessary to have some legislative provisions for the specific cases when physical persons can be involved in entrepreneurial activities without the state registration as individual entrepreneurs. They also state that a favorable business and investment climate and business conditions can be achieved, on the one hand, by state stimulation of legal entrepreneurial activities and, on the other hand, by establishing the wellgrounded criteria for criminalizing actions in the sphere of entrepreneurship. The authors also stress the importance of further research of the analyzed concept for identifying the crime-defining features and for a better classification of crimes in the sphere of entrepreneurship.
Предпринимательская деятельность относится к числу базовых юридических категорий, она не только раскрывает предмет и сущность предпринимательского права, но и имеет важное значение для уголовного права [1; 2] и других отраслей права. С ее осуществлением может быть связано возникновение как гражданских и предпринимательских, так и уголовных и административных правоотношений [3]. Несмотря на свое легальное определение в п. 1 ст. 2 ГК РФ ${ }^{1}$, она, тем не менее, продолжает быть предметом многих юридических исследований [4-6] и не имеет однозначного понимания в правовой науке, и в первую очередь в самом предпринимательском праве [7-9]. Особую актуальность исследование предпринимательской деятельности приобретает сегодня в связи с изменениями, внесенными в 2017 г. в законодательное ее определение в ГК РФ².

Итак, в настоящее время предпринимательская деятельность определяется как «самостоятельная, осуществляемая на свой риск деятельность, направленная на систематическое получение прибыли от пользования имуществом, продажи товаров, выполнения работ или оказания услуг» (п. 1 ст. 2 ГК РФ). Именно такое определение предпринимательской деятельности положено и в основу формирования конститутивных признаков уголовно наказуе-

1 Гражданский кодекс Российской Федерации. Часть 1 : федер. закон от 30 нояб. 1994 г. № 51-Ф3 // Собрание законодательства РФ. 1994. № 32. Ст. 3301.

2 О внесении изменений в статьи 2 и 23 части первой Гражданского кодекса Российской Федерации : федер. закон от 26 июля 2017 г. № 199-ФЗ // Там же. 2017. № 31. Ст. 4748. мых деяний. Таким образом, действующее законодательство предусматривает три следующих квалифицирующих признака предпринимательской деятельности.

Во-первых, самостоятельность, которая в теории предпринимательского права раскрывается через две составляющие: имущественную самостоятельность, предусматривающую наличие у субъекта предпринимательской деятельности определенного имущества как экономической базы для ведения такой деятельности, и хозяйственную (организационную) самостоятельность, предполагающую возможность принятия самостоятельных решений в процессе предпринимательской деятельности [10, с. 17-18].

Во-вторых, наличие риска, означающего возможность наступления неблагоприятных имущественных последствий от предпринимательской деятельности - неполучение ожидаемых доходов и возникновение убытков, в том числе из-за нарушения своих обязательств контрагентами предпринимателя или изменения условий этой деятельности по независящим от предпринимателя обстоятельствам ${ }^{3}$. Он также может заключаться в вероятности наступления событий, в результате которых продолжение осуществления данной деятельности станет невозможным 4 .

${ }^{3}$ Об организации страхового дела в Российской Федерации : закон РФ от 27 нояб. 1992 г. № 4015-І // Ведомости Съезда народных депутатов Российской Федерации и Верховного Совета Российской Федерации. 1993. № 2. СТ. 56.

${ }^{4}$ Дело № A11-11450/2011 [Электронный ресурс] : постановление Федер. арбитраж. суда Волго-Вят. окр. от 18 янв. 2013 г. № Ф01-5635/12 // ИПС «Гарант». 
В-третьих, направленность на систематическое получение прибыли от пользования имуществом, продажи товаров, выполнения работ или оказания услуг, которую следует признать в качестве основного квалифицирующего признака предпринимательской деятельности, поскольку другие вышеназванные особенности могут быть характерны и для других видов деятельности. В то же время он является и наиболее сложным в части определения характера осуществляемой деятельности [11, с. 12].

Дело в том, что прибыль может вообще отсутствовать, что в определенной мере корреспондирует с вышеуказанным признаком о наличии риска в предпринимательской деятельности. В этой связи справедливо было отмечено В п. 13 постановления Пленума Верховного Суда Российской Федерации «О некоторых вопросах, возникающих у судов при применении Особенной части Кодекса Российской Федерации об административных правонарушениях» от 24 октября 2006 г. № 185, что само по себе отсутствие прибыли не влияет на квалификацию правонарушений, предусмотренных ст. 14.1 КоАП РФ поскольку извлечение прибыли является целью предпринимательской деятельности, а не ее обязательным результатом.

Факт совершения сделок на возмездной основе также не является достаточным основанием для квалификации предпринимательской деятельности. Необходимо наличие систематического характера извлечения прибыли, который, к сожалению, в законодательстве не раскрывается, а вопрос о минимальном количестве сделок (две, три или более?) до сих пор в литературе однозначно не разрешен [12, с. 41-42]. В то же время нельзя исключать возможность признания даже одной отдельной сделки в качестве предпринимательской. Так, в соответствии с приведенным выше п. 13 постановления Пленума Верховного Суда РФ «О некоторых вопросах, возникающих у судов при применении Особенной части Кодекса Российской Федерации об административных правонарушениях» от 24 октября 2006 г. № 18 «отдельные случаи

5 О некоторых вопросах, возникающих у судов при применении Особенной части Кодекса Российской Федерации об административных правонарушениях [Электронный ресурс] : постановление Пленума Верхов. Суда РФ от 24 окт. 2006 г. № 18 // ИПС «Гарант».

${ }^{6}$ Кодекс Российской Федерации об административных правонарушениях : федер. закон от 30 дек. 2001 г. № 195-Ф3 // Собрание законодательства РФ. 2002. № 1. СТ. 1. продажи товаров, выполнения работ, оказания услуг лицом, не зарегистрированным в качестве индивидуального предпринимателя, не образуют состав данного административного правонарушения при условии, если количество товара, его ассортимент, объемы выполненных работ, оказанных услуг и другие обстоятельства не свидетельствуют о том, что данная деятельность была направлена на систематическое получение прибыли». Отсюда можно сделать вывод о том, что отдельные случаи продажи товаров, выполнения работ, оказания услуг могут квалифицироваться в качестве предпринимательской деятельности (при наличии вышеназванных условий). Нельзя не обратить внимание также и на то, что получение дохода не означает извлечения прибыли, поскольку они представляют собой разные понятия: обычно прибыль - это полученные доходы, уменьшенные на величину произведенных расходов (247 НК РФ7).

Судебная практика исходит из системного толкования правила п. 1 ст. 2 ГК РФ о предпринимательской деятельности, справедливо указывая на необходимость учета многих обстоятельств дела. В частности, на наличие в действиях гражданина признаков предпринимательской деятельности могут указывать такие факты, как: количество переданного за плату товара, его ассортимент, объемы выполненных работ, оказанных услуг; размещение рекламных объявлений; выставление образцов товаров в местах продажи; закупка товаров и материалов; заключение договоров аренды помещений ; хозяйственный учет операций, связанных с осуществлением сделок; взаимосвязанность всех совершаемых гражданином в определенный период времени сделок; устойчивые связи с продавцами, покупателями, прочими контрагентами 9 .

Показательным в практике разграничения деяний является дело о привлечении гражданина к административной ответственности, установленной ч. 1 ст. 14.1 КоАП РФ, за осуществление предпринимательской деятельности без

7 Налоговый кодекс Российской Федерации. Часть 2 : федер. закон от 5 авг. 2000 г. № 117-Ф3 // Собрание законодательства РФ. 2000. № 32. Ст. 3340.

${ }^{8}$ О некоторых вопросах, возникающих у судов при применении Особенной части Кодекса Российской Федерации об административных правонарушениях : постановление Пленума Верхов. Суда РФ от 24 окт. 2006 г. № 18. Пункт 13 // Российская газета. 2006. 8 нояб.

${ }^{9}$ Дело № A11-11450/2011 [Электронный ресурс] : постановление Федер. арбитраж. суда Волго-Вят. окр. от 18 янв. 2013 г. № Ф01-5635/12 // ИПС «ГаранТ». 
государственной регистрации или без специального разрешения (лицензии). Мировой судья и вышестоящие судебные инстанции, казалось бы, справедливо исходили из того, что сдача внаем посуточно и по часам жилого помещения является предпринимательской деятельностью. Однако с таким выводом не согласился Верховный Суд Российской Федерации ${ }^{10}$. Он отменил постановление мирового судьи, решение судьи районного суда и постановление заместителя председателя краевого суда и прекратил производство по данному делу в связи с отсутствием события административного правонарушения, сославшись на письмо Министерства Российской Федерации по налогам и сборам «О сдаче помещений в аренду (наем)» от 6 июля 2004 г. № 043-01/398, Управления Министерства Российской Федерации по налогам и сборам по г. Москве от 10 октября 2003 г. № 27-11н/56495, Управления Федеральной налоговой службы по г. Москве от 6 сентября 2006 г. № 28-11/80621, в соответствии с которым сдача квартиры внаем выступает одним из способов реализации законного права гражданина на распоряжение принадлежащим ему на праве собственности имуществом и не является предпринимательской деятельностью. Кроме того, он обратил внимание на п. 2 постановления Пленума Верховного Суда Российской Федерации «О судебной практике по делам о незаконном предпринимательстве и легализации (отмывании) денежных средств или иного имущества, приобретенных преступным путем» от 18 ноября 2004 г. № $23^{11}$, согласно которому в тех случаях, когда не зарегистрированное в качестве индивидуального предпринимателя лицо приобрело для личных нужд жилое помещение или иное недвижимое имущество либо получило его по наследству или по договору дарения, но в связи с отсутствием необходимости в использовании этого имущества временно сдало его в аренду или внаем и в результате такой гражданско-правовой сделки получило доход (в том числе в крупном или особо крупном размере), содеянное им не влечет уголовной ответственности за незаконное предпринимательство.

До 2017 г. квалифицирующим признаком предпринимательской деятельности выступала

10 Постановление Верховного Суда РФ от 10 января 2012 г. № 51-АД11-7. URL: http://www.garant.ru/ products/ipo/prime/doc/70043184/\#ixzz4wFKFFOQc.

11 URL: http://www.garant.ru/products/ipo/prime/ doc/1253895/\#ixzz4wFOy5aJ3. легитимация посредством проведения государственной регистрации лиц в качестве субъектов предпринимательской деятельности в установленном законом порядке. В этой связи отсутствие регистрации гражданина в качестве индивидуального предпринимателя до 2017 г., как правило, указывало на отсутствие предпринимательской деятельности, хотя в ряде случаев не исключало применения правил ГК РФ об обязательствах, связанных с осуществлением предпринимательской деятельности (п. 4 ст. 23 ГК РФ).

В определенной мере такое понимание предпринимательской деятельности корреспондировало с германским (субъективным) подходом, основанным на признании предпринимателями лиц, прямо перечисленных в законе. В Германии такие лица включаются в торговый реестр в качестве предпринимателей. В частности, там принято различать несколько видов предпринимателей: так называемые обязательные коммерсанты (ist Kaufmann), коммерсанты по желанию (kann Kaufmann), коммерсанты в силу правовой формы (Formkaufmann) [13, с. 32-33].

Согласно французскому (объективному) подходу, предпринимателями признаются любые лица, которые совершают торговые сделки в процессе осуществления своей обычной профессии (ст. 1 Французского торгового кодекса), т.е. объективно ведут предпринимательскую деятельность. При этом законодательство соответствующей страны обычно содержит примерный (иногда исчерпывающий) перечень сделок или хозяйственных операций, которые признаются торговыми, а сама предпринимательская деятельность может быть начата после внесения сведений о предпринимателе в торговый реестр [там же, с. 98-100].

В настоящее время, как уже было отмечено, легитимация субъекта предпринимательской деятельности исключена из легального определения такой деятельности. В то же время в п. 1 ст. 2 ГК РФ указывается, что лица, осуществляющие предпринимательскую деятельность, должны быть зарегистрированы в этом качестве в установленном законом порядке, если иное не предусмотрено ГК РФ (п. 1 ст. 2 ГК РФ). Гражданин вправе заниматься предпринимательской деятельностью без образования юридического лица с момента государственной регистрации в качестве индивидуального предпринимателя за исключением случаев, когда в отношении отдельных видов предпринимательской деятельности законом могут быть предусмотрены 
условия осуществления гражданами такой деятельности без государственной регистрации в качестве индивидуального предпринимателя (п. 1 ст. 23 ГК РФ). В этой связи возникает резонный вопрос: о каких отдельных видах предпринимательской деятельности идет речь, с учетом того что в настоящее время отсутствуют соответствующие законодательные положения, не говоря уже об отдельном федеральном законе по этому вопросу?

Возвращаясь к истории принятия поправок В ГК РФ, следует указать на цель внесения рассматриваемых изменений - определить правовой статус физических лиц, оказывающих на индивидуальной основе по найму некоторые виды услуг физическим лицам без регистрации в качестве индивидуальных предпринимателей. Предполагается, что в данном случае граждане могут быть освобождены от необходимости несения зачастую обременительных обязанностей, установленных для индивидуальных предпринимателей, что позволит снизить уровень неформальной занятости экономически активного населения и исключить признание деятельности самозанятых граждан незаконным предпринимательством ${ }^{12}$.

Другими словами, нововведение рассчитано на такие виды деятельности, как, например, сдача квартиры гражданами внаем за плату. Исходя из действующего законодательства лица, осуществляющие данную деятельность, не должны регистрироваться в качестве индивидуальных предпринимателей, но при условии, что это будет прямо установлено в законе. Решение проблемы осложняется еще тем, что ранее судебная практика, в первую очередь названная выше позиция Верховного Суда РФ, не признавала сдачу квартиры гражданами внаем за плату в качестве предпринимательской деятельности.

Более того, в законодательстве можно встретить отдельные положения, прямо указывающие на то, что тот или иной вид деятельности относится к предпринимательству и, наоборот, когда он по сути соответствует признакам предпринимательской деятельности, но таковой не является. К примеру, в качестве предпринимательской деятельности прямо указываются торговая де-

12 Пояснительная записка к проекту федерального закона № 87981-7 «О внесении изменений в статьи 2 и 23 части первой Гражданского кодекса Российской Федерации». URL: http://sozd.parlament.gov.ru/bill/87981-7. ятельность ${ }^{13}$, ведение фермерского хозяйства ${ }^{14}$, промышленное и прибрежное рыболовство ${ }^{15}$ и др. Напротив, существуют виды деятельности, которые не признаются законом предпринимательской, например реализация гражданами, ведущими личное подсобное хозяйство, сельскохозяйственной продукции, произведенной и переработанной при ведении личного подсобного хозяйства ${ }^{16}$. Нельзя забывать, что существует также профессиональная деятельность, не признаваемая в качестве предпринимательской: нотариальная ${ }^{17}$, адвокатская ${ }^{18}$, деятельность арбитров в рамках арбитража (третейского разбирательства) $)^{19}$ и т.д. Различие между субъектами предпринимательской и профессиональной деятельности проводит и Федеральный закон «О саморегулируемых организациях» от 1 декабря 2007 г. № 315-Ф320, который регулирует деятельность саморегулируемых организаций, объединяющих субъектов предпринимательской или профессиональной деятельности.

Таким образом, в настоящее время в ГК РФ акцент смещен в сторону объективного понимания предпринимательской деятельности, что, представляется, может изменить практику квалификации деяния в процессе расследования и рассмотрения уголовных дел по экономическим

13 Об основах государственного регулирования торговой деятельности в Российской Федерации : федер. закон от 28 дек. 2009 г. № 381-Ф3. Пункт 1 ст. 2 // Собрание законодательства РФ. 2010. № 1. СТ. 2.

14 О крестьянском (фермерском) хозяйстве : федер. закон от 11 июня 2003 г. № 74-Ф3. Пункт 3 ст. 1 // Там же. 2003. № 24. Ст. 2249.

${ }^{15}$ О рыболовстве и сохранении водных биологических ресурсов : федер. закон от 20 дек. 2004 г. № 166Ф3. Пункты 10 и 10.1 ч. 1 ст. 1 // Там же. 2004. № 52. СТ. 5270.

${ }^{16}$ О личном подсобном хозяйстве : федер. закон от 7 июля 2003 г. № 112-Ф3. Пункт 4 ст. 2 // Там же. 2003. № 28. Ст. 2881.

17 Основы законодательства Российской Федерации о нотариате : федер. закон от 11 февр. 1993 г. № 4462-І. Часть 6 ст. 1 // Ведомости Съезда народных депутатов Российской Федерации и Верховного Совета Российской Федерации. 1993. № 10. Ст. 357.

18 Об адвокатской деятельности и адвокатуре в Российской Федерации : федер. закон от 31 мая 2002 г. № 63-Ф3. Пункт 2 ст. 1 // Собрание законодательства РФ. 2002. № 23. Ст. 2102.

${ }^{19}$ Об арбитраже (третейском разбирательстве) в Российской Федерации : федер. закон от 29 дек. 2015 г. № 382-Ф3. Пункт 1 ст. 2 // Там же. 2016. № 1. Ст. 2.

20 О саморегулируемых организациях : федер. закон от 1 дек. 2007 г. № 315-Ф3 // Там же. 2007. № 49. Ст. 6076 . 
преступлениям, а также применения к подозреваемым и обвиняемым мер пресечения. Дело в том, что, согласно п. 7 постановления Пленума Верховного Суда РФ «О практике применения судами законодательства, регламентирующего особенности уголовной ответственности за преступления в сфере предпринимательской и иной экономической деятельности» от 15 ноября 2016 г. № 48, при рассмотрении вопроса об избрании меры пресечения в виде заключения под стражу в отношении подозреваемого или обвиняемого в преступлениях, предусмотренных ч. 1-4 ст. 159, ст. 159.1-159.3, 159.5, 159.6, 160 и 165 УК РФ, суд должен выяснить, совершены ли эти преступления в сфере предпринимательской деятельности. Для разрешения вопроса о предпринимательском характере деятельности судам надлежит иметь в виду, что предпринимательской является самостоятельная, осуществляемая на свой риск деятельность, направленная на систематическое получение прибыли от пользования имуществом, продажи товаров, выполнения работ или оказания услуг лицами, зарегистрированными в этом качестве в установленном законом порядке. С учетом этого указанные преступления следует считать совершенными в сфере предпринимательской деятельности, если они совершены индивидуальным предпринимателем в связи с осуществлением им предпринимательской деятельности и (или) управлением принадлежащим ему имуществом, используемым в целях предпринимательской деятельности, а также членом органа управления коммерческой организации в связи с осуществлением им полномочий по управлению организацией либо при осуществлении коммерческой организацией предпринимательской деятельности ${ }^{21}$. Как видно, данное разъяснение исходит из ранее действовавшего определения предпринимательской деятельности, тогда как согласно новому пониманию меры пресечения в виде заключения под стражу в отношении подозреваемого или обвиняемого могут быть применены в отношении не только индивидуального предпринимателя, но и любого гражданина в связи с осуществлением им предпринимательской деятельности.

${ }^{21}$ О практике применения судами законодательства, регламентирующего особенности уголовной ответственности за преступления в сфере предпринимательской и иной экономической деятельности [Электронный ресурс] : постановление Пленума Верхов. Суда РФ от 15 нояб. 2016 г. № 48. Пункт 7 // ИПС «Гарант».
Представляется, что без четкого определения предпринимательской деятельности не обойтись. Для правовой оценки анализируемых действий требуется использование дополнительных (уточняющих) признаков предпринимательской деятельности. В первую очередь необходимо обратить внимание, что предпринимательскую деятельность следует рассматривать как разновидность экономической деятельности. На это указывает АПК РФ 22 во многих своих положениях. К примеру, правосудие в сфере предпринимательской и иной экономической деятельности осуществляется арбитражными судами в Российской Федерации (ст. 1 АПК РФ). Арбитражному суду подведомственны дела по экономическим спорам и другие дела, связанные с осуществлением предпринимательской и иной экономической деятельности (ч. 1 ст. 27 АПК РФ).

Такое понимание позволяет отграничить от предпринимательства иные виды деятельности, в частности любую творческую или профессиональную деятельность. При этом под экономической, или хозяйственной, деятельностью в литературе обычно понимают деятельность стоимостного характера по вложению, производству, распределению и обмену материальных и духовных благ. Она включает в себя, в частности, производство и реализацию товаров, выполнение работ и оказание услуг, приобретение и реализацию иного имущества, участие в юридических лицах [14, с. 9].

Подобное определение, но в отношении хозяйственной деятельности предусмотрено также в п. 1 ст. 3 Хозяйственного кодекса Украины ${ }^{23}$ : это деятельность субъектов хозяйствования в сфере общественного производства, направленная на изготовление и реализацию продукции, выполнение работ либо оказание услуг стоимостного характера, имеющих ценовую определенность. Соответственно, она может представлять собой предпринимательство (если осуществляется для достижения экономических и социальных показателей и с целью получения прибыли) или некоммерческую хозяйственную деятельность (п. 2 ст. 3 Хозяйственного кодекса Украины).

В этой связи становится понятно, что предпринимательскую деятельность, в отличие от

${ }^{22}$ Арбитражный процессуальный кодекс Российской Федерации : федер. закон от 24 июля 2002 г. № 95-Ф3 // Собрание законодательства РФ. 2002. № 30. Ст. 3012.

23 URL: http://yurist-online.org/laws/codes/hoz/ hozyaistvennyi_kodeks_na_russkom.pdf. 
иной экономической, могут осуществлять далеко не любые субъекты права. В частности, это касается государства - публично-правового образования, деятельность которого априори направлена не на систематическое извлечение прибыли, а на выполнение внутренних и внешних функций государства, хотя в литературе можно встретить иную позицию по этому вопросу [15]. Существуют некоммерческие организации, которые могут осуществлять приносящую доход деятельность, если это предусмотрено их уставами, причем лишь постольку, поскольку это служит достижению целей, ради которых они созданы, и если это соответствует таким целям (п. 4 ст. 50 ГК РФ). В п. 2 ст. 24 Федерального закона «О некоммерческих организациях» от 12 января 1996 г. № 7-Ф3 предусмотрено несколько иное положение: некоммерческая организация может осуществлять предпринимательскую и иную приносящую доход деятельность лишь постольку, поскольку это служит достижению целей, ради которых она создана, и соответствует указанным целям, при условии, что такая деятельность указана в его учредительных документах ${ }^{24}$. Такой деятельностью признаются приносящее прибыль производство товаров и услуг, отвечающих целям создания некоммерческой организации, а также приобретение и реализация ценных бумаг, имущественных и неимущественных прав, участие в хозяйственных обществах и участие в товариществах на вере в качестве вкладчика.

Нельзя также не обратить внимание на то, что далеко не любой риск может являться признаком предпринимательской деятельности. В нашем случае следует вести речь именно о предпринимательском риске - вероятности наступления неблагоприятных имущественных последствий в предпринимательской сфере, начиная с возникновения убытков и заканчивая банкротством.

Наконец, представляет интерес использование дополнительных критериев, предложенных в науке, законодательстве и даже судебной практике, которые в определенной степени отражают или развивают законодательные признаки предпринимательской деятельности: профессионализм [16, с. 20-21], или осуществление деятельности с применением профессиональных знаний и опыта, направленных на мини-

24 Собрание законодательства РФ. 1996. № 3. Ст. 145 ; 2010. № 19. Ст. 2291. мизацию рисков ${ }^{25}$; инициативность ${ }^{26}$; наличие обособленного имущества на праве частной собственности либо на праве хозяйственного ведения или оперативного управления государственного предприятия ${ }^{27}$; самостоятельная имущественная ответственность ${ }^{28}$; использование материальных и нематериальных ресурсов, создание рабочих мест, производство товара [17]; новаторский, или инновационный характер; предназначение товаров, работ и услуг для реализации другим лицам, а не для собственного потребления ${ }^{29}$ и др. Вместе с тем в литературе можно встретить и критику в отношении ряда предлагаемых признаков.

Учитывая все это, перечисление в законе случаев, указывающих на наличие или отсутствие предпринимательской деятельности, значительно облегчило бы задачу ее определения как для самих предпринимателей, так и для правоприменителя. В этой связи заслуживает внимания опыт Республики Беларусь. В п. 1 ст. 1 ГК Республики Беларусь прямо перечисляются виды деятельности, которые не признаются в качестве предпринимательской, например: ремесленная деятельность; деятельность граждан Республики Беларусь, осуществляющих ведение личных подсобных хозяйств, по производству, переработке и реализации произведенной ими сельскохозяйственной продукции; адвокатская деятельность; нотариальная деятельность нотариусов; деятельность третейских судей; деятельность, осуществляемая в рамках временных научных коллективов; репетиторство; чистка и уборка жилых помещений; деятельность актеров, танцоров, музыкантов, исполнителей разговорного жанра, выступающих индивидуально; сдача внаем (поднаем) жилых помещений, кроме предоставления мест для краткосрочного проживания, и т.д.

Таким образом, предусмотренное в ГК РФ легальное определение предпринимательской деятельности, имеющее межотраслевое значение,

25 Дело № A45-7597/2015 [Электронный ресурс] : постановление Арбитраж. суда Зап.-Сиб. окр. от 3 марта 2016 г. № Ф04-343/16 // ИПС «Гарант».

26 Предпринимательский кодекс Республики Казахстан от 29 октября 2015 г. № 375-V. Пункт 1 ст. 2. URL: http://online.zakon.kz.

${ }^{27}$ Там же.

28 Гражданский кодекс Республики Беларусь от 7 декабря 1998 г. № 218-3. Пункт 1 ст. 1. URL: http:// online.zakon.kz/Document/?doc_id=30415161.

29 Там же. 
является неточным и не позволяет в полной мере отграничить ее от других видов деятельности, в первую очередь от иной экономической или профессиональной деятельности. Оно требует своего более детального уточнения, в частности путем указания на экономический вид деятельности и предпринимательский характер риска, раскрытия признака систематического извлечения прибыли и законодательного установления перечня видов деятельности, не признаваемых в качестве предпринимательской [18-21]. Кроме того, в связи с исключением требования легитимации из легального определения предпринимательской деятельности на законодательном уровне необходимо предусмотреть случаи, когда в отношении отдельных видов предпринимательской деятельности граждане могут осуществлять такую деятельность без государственной регистрации в качестве индивидуального предпринимателя. Это, в свою очередь, будет способствовать разграничению правомерного и неправомерного деяний [22, с. 24] и формированию оптимальных конструкций составов правонарушений в отраслевом законодательстве, предусматривающем ответственность за незаконную предпринимательскую деятельность.

\section{СПИСОК ИСПОЛЬЗОВАННОЙ ЛИТЕРАТУРЫ}

1. Jefferson M. Regulation, businesses, and criminal liability / M. Jefferson // The Journal of Criminal Law. - 2011. - Vol. 75, № 1. - P. 37-44.

2. Tilley N. Organized crime and local businesses / N. Tilley // Criminology \& Criminal Justice. - 2008. - Vol. 8, № 4. P. $443-459$.

3. Уголовное право России. Части Общая и Особенная / под ред. А.В. Бриллиантова. - М. : Проспект, 2015. - 1184 с.

4. Commentary on the unidroit Principles of International Commercial Contracts (PICC) / ed. St. Vogenauer, J. Kleinheisterkamp. - Oxford : Univ. Press, 2009. - 139 p.

5. Barret O. Vente. Repertoire de droit civil. Janvier 2007 (actualization: janvier 2016).

6. Hill J. International Commercial Disputes: Commercial Conflict of Laws in English Courts / J. Hill, A. Chong. $-4^{\text {th }}$ ed. $-\mathrm{Ox}-$ ford : Hart Published, 2010. - 940 p.

7. Шестак B.А. Отдельные вопросы предупреждения преступных посягательств в сфере экономики / B.A. Шестак // LeX Russica. - 2007. - № 5. - С. 951-958.

8. Ершова И.В. Понятие предпринимательской деятельности в теории и судебной практике / И.В. Ершова // Lex Russica. - 2014. - № 2. - С. 160-167.

9. Олейник О.М. Формирование критериев квалификации предпринимательской деятельности в судебной практике / О.М. Олейник // Предпринимательское право. - 2013. - № 1. - С. 2-17.

10. Российское предпринимательское право / отв. ред. И.В. Ершова, Г.Д. Отнюкова. - М. : Проспект, 2006. - 1064 с.

11. Предпринимательское право России / отв. ред. В.С. Белых. - М. : Проспект, 2009. - 656 с.

12. Белых В.С. Правовое регулирование предпринимательской деятельности в России / В.С. Белых. - М. : Проспект, 2010. -432 c.

13. Коммерческое право зарубежных стран / под ред. В.Ф. Попондопуло. - СПб. : Питер, 2003. - 288 с.

14. Знаменский Г.Л. Новое хозяйственное право. Избранные труды / Г.Л. Знаменский. - Киев : Юринком Интер, 2012. -488 c.

15. Кондратенко 3.К. Предпринимательская деятельность муниципальных образований / З.К. Кондратенко, Г.Ю. Шабалин // Марийский юридический вестник. - 2016. - № 4 (19). - С. 86-88.

16. Предпринимательское (хозяйственное) право : в 2 т. / под ред. О.М. Олейник. - М. : Юристь, 2000. - Т. 1. - 727 с. $1008 \mathrm{c}$.

17. Предпринимательское право Российской Федерации / отв. ред. Е.П. Губин, П.Г. Лахно. - М. : Инфра-М, 2010. -

18. Олейник О.М. Понятие предпринимательской деятельности: теоретические проблемы формирования / О.М. Олейник // Предпринимательское право. - 2015. - № 1. - С. 3-17.

19. Мороз С.П. Предпринимательское (хозяйственное) право / С.П. Мороз. - Алматы : Бастау, 2009. - 266 с.

20. Лаптев В.В. Предпринимательское (хозяйственное) право. Избранные труды / В.В. Лаптев. - Екатеринбург : Бизнес, менеджмент, право, 2008. - 536 с.

21. Шумпетер Й. Теория экономического роста / Й. Шумпетер. - М. : Прогресс, 1982. -455 с.

22. Шестак В.А. Современные особенности привлечения к уголовной ответственности за преступления в сфере предпринимательской и иной экономической деятельности / В.А. Шестак // Российская юстиция. - 2017. - № 10. - С. $24-27$.

\section{REFERENCES}

1. Jefferson M. Regulation, businesses, and criminal liability. The Journal of Criminal Law, 2011, vol. 75, no. 1, pp. 37-44.

2. Tilley N. Organized crime and local businesses. Criminology \& Criminal Justice, 2008, vol. 8, no. 4, pp. 443-459.

3. Brilliantov A.V. (ed.). Ugolovnoe pravo Rossii. Chasti Obshchaya i Osobennaya [Criminal Law of Russia. General and Special Parts]. Moscow, Prospekt Publ., 2015. 1184 p.

4. Vogenauer St., Kleinheisterkamp J. (eds.). Commentary on the unidroit Principles of International Commercial Contracts (PICC). Oxford, University Press, 2009. 139 p.

5. Barret O. Vente. Repertoire de droit civil. Janvier 2007 (actualization: janvier 2016). 
6. Hill J., Chong A. International Commercial Disputes: Commercial Conflict of Laws in English Courts. $4^{\text {th }}$ ed. Oxford, Hart Published, 2010. 940 p.

7. Shestak V.A. Some aspects of preventing criminal offences in the sphere of economy. Lex Russica, 2007, no. 5, pp. 951-958. (In Russian).

8. Ershova I.V. The concept of entrepreneurial activities in theory and court practice. Lex Russica, 2014, no. 2, pp. $160-167$. (In Russian).

9. Oleinik O.M. Forming the criteria for qualifying entrepreneurial activities in court practice. Predprinimatel'skoe pravo = Entrepreneurial Law, 2013, no. 1, pp. 2-17. (In Russian).

10. Ershova I.V., Otnyukova G.D. (eds.). Rossiiskoe predprinimatel'skoe pravo [Russian Entrepreneurial Law]. Moscow, Prospekt Publ., 2006. 1064 p.

11. Belykh V.S. (ed.). Predprinimatel'skoe pravo Rossii [Entrepreneurial Law of Russia]. Moscow, Prospekt Publ., 2009. 656 p.

12. Belykh V.S. Pravovoe regulirovanie predprinimatel'skoi deyatel'nosti v Rossii [Legal Regulation of Entrepreneurial Activities in Russia]. Moscow, Prospekt Publ., 2010. 432p.

13. Popondopulo V.F. (ed.). Kommercheskoe pravo zarubezhnykh stran [Commercial Law of Foreign Countries]. Saint Petersburg, Piter Publ., 2003. 288 p.

14. Znamenskii G.L. Novoe khozyaistvennoe pravo. Izbrannye trudy [New Business Law. Selected Works]. Kiev, Yurinkom Inter Publ., 2012. 488 p.

15. Kondratenko Z.K., Shabalin G.Yu. Entrepreneurial activities of municipalities. Mariiskii yuridicheskii vestnik = Mari Legal Bulletin, 2016, no. 4 (19), pp. 86-88. (In Russian).

16. Oleinik O.M. (ed.). Predprinimatel'skoe (khozyaistvennoe) pravo [Entrepreneurial (Business) Law]. Moscow, Yurist"Publ., 2000. Vol. 1. 727 p.

17. Gubin E.P., Lakhno P.G. (eds.). Predprinimatel'skoe pravo Rossiiskoi Federatsii [Entrepreneurial Law of the Russian Federation]. Moscow, Infra-M Publ., 2010. 1008 p.

18. Oleinik O.M. The concept of entrepreneurial activity: the theoretical issues of formation. Predprinimatel'skoe pravo = Entrepreneurial Law, 2015, no. 1, pp. 3-17. (In Russian). 266 p.

19. Moroz S.P. Predprinimatel'skoe (khozyaistvennoe) pravo [Entrepreneurial (Business) Law]. Almaty, Bastau Publ., 2009.

20. Laptev V.V. Predprinimatel'skoe (khozyaistvennoe) pravo. Izbrannye Trudy [Entrepreneurial (Business) Law. Selected Works]. Yekaterinburg, Biznes, Menedzhment, Pravo Publ., 2008. 536 p.

21. Shumpeter Y. Theorie der wirtschaftlichen entwicklung: eine untersuchung über unternehmergewinn, kapital, kredit, zins und den konjunkturzyklus. Duncker \& Humblot, 1931. 369 S. (Russ. ed.: Shumpeter I. Teoriya ekonomicheskogo rosta. Moscow, Progress Publ., 1982, 455 p.).

22. Shestak V.A. Modern characteristics of persecuting for crimes in the sphere of entrepreneurship and other economic activities. Rossiiskaya yustitsiya = Russian Justice, 2017, no. 10, pp. 24-27. (In Russian).

\section{ИНФОРМАЦИЯ ОБ АВТОРАХ}

Лисица Валерий Николаевич - заведующий кафедрой предпринимательского права, гражданского и арбитражного процесса Института философии и права Новосибирского государственного университета, профессор кафедры гражданского и предпринимательского права Новосибирского государственного университета экономики и управления, доктор юридических наук, доцент, г. Новосибирск, Российская Федерация; e-mail: lissitsa@mail.ru.

Пархоменко Светлана Валерьевна - профессор кафедры уголовно-правовых дисциплин Иркутского юридического института (филиала) Академии Генеральной прокуратуры Российской Федерации, доктор юридических наук, профессор, государственный советник юстиции 3-го класса, г. Иркутск, Российская Федерация; e-mail: psvet@mail.ru.

\section{ДЛЯ ЦИТИРОВАНИЯ}

Лисица В.Н. Некоторые аспекты повышения эффективности уголовного закона в сфере экономики: разработка категориального аппарата / В.Н. Лисица, С.В. Пархоменко // Всероссийский криминологический журнал. - 2018. - T. 12, № 2. - C. 190-198. - DOI: 10.17150/2500-4255.2018.12(2).190-198.

\section{INFORMATION ABOUT THE AUTHORS}

Lisitsa, Valeriy N. - Head, Chair of Business Law, Civil and Arbitral Process, Institute of Philosophy and Law, Novosibirsk State University, Professor, Chair of Civil and Business Law, Novosibirsk State University of Economics and Management, Doctor of Law, Ass. Professor, Novosibirsk, the Russian Federation; e-mail: lissitsa@mail.ru.

Parkhomenko, Svetlana V. - Professor, Chair of Criminal Law Disciplines, the Irkutsk Law Institute (branch) of the Academy of General Prosecutor's Office of the Russian Federation, Doctor of Law, Professor, State Councilor of Justice, $3^{\text {rd }}$ class, Irkutsk, the Russian Federation; e-mail: psvet@mail.ru.

\section{FOR CITATION}

Lisitsa V.N., Parkhomenko S.V. Some aspects of improving the efficiency of criminal law in the sphere of economy: developing the categories. Vserossiiskii kriminologicheskii zhurnal = Russian Journal of Criminology, 2018, vol. 12, no. 2, pp. 190-198. DOI: 10.17150/2500-4255.2018.12(2).190-198. (In Russian). 